\title{
Impacts of Sewage Sludge in Tropical Soil: A Case Study in Brazil
}

\author{
Wagner Bettiol and Raquel Ghini \\ Embrapa Environment, CP 69, 13820-000 Jaguariúna, SP, Brazil \\ Correspondence should be addressed to Wagner Bettiol, bettiol@cnpma.embrapa.br
}

Received 25 November 2010; Accepted 26 January 2011

Academic Editor: Rodrigo Studart Corrêa

Copyright (C) 2011 W. Bettiol and R. Ghini. This is an open access article distributed under the Creative Commons Attribution License, which permits unrestricted use, distribution, and reproduction in any medium, provided the original work is properly cited.

\begin{abstract}
A long-term assay was conducted to evaluate the environmental impacts of agriculture use of sewage sludge on a tropical soil. This paper describes and discusses the results obtained by applying a interdisciplinary approach and the valuable insights gained. Experimental site was located in Jaguariúna (SP, Brazil). Multiyear comparison was developed with the application of sewage sludge obtained from wastewater treatment plants at Barueri (domestic and industrial sewage) and Franca (domestic sewage), São Paulo State. The treatments were control, mineral fertilization, and sewage sludge applied based on the $\mathrm{N}$ concentration that provides the same amount of $\mathrm{N}$ as in the mineral fertilization recommended for corn crop, two, four, and eight times the $\mathrm{N}$ recommended dosage. The results obtained indicated that the amount of sewage sludge used in agricultural areas must be calculated based on the $\mathrm{N}$ crop needs, and annual application must be avoided to prevent overapplications.
\end{abstract}

\section{Introduction}

Sewage sludge contains organic matter and is rich in macroand micronutrients, so the agricultural and forestry disposal is widely recommended [1-3]. However, sewage sludge also contains contaminants (heavy metals, organic compounds, and human pathogens) which should be considered when it is utilized in agricultural and forestry soils $[1,4]$. Researches about sewage sludge disposal in soil are focused on its effects on soil fertility, plant development, and contamination by heavy metals and organic compounds. However, applications of this residue modify biological, chemical, and physical properties of the soils, consequently the dynamics of its microbiota, organic matter decomposition, nutrient cycling, physical structure of the soil, and pest and plant disease severity $[4-10]$.

The studies on sewage sludge are conducted mainly under temperate conditions, with few studies in tropical climate. The few studies in tropical conditions are conducted mainly to assess the nutritional effects and problems with heavy metal from sewage sludge application. These studies are rarely performed by determining long-term environmental impacts of agricultural use of sewage sludge.
Due to the fact that sewage sludge amount in Brazil is rapidly increasing, since its production was initiated twenty years ago, it is extremely important to gain knowledge and to learn about the long-term effects of sewage sludge applications on soil chemical, biological, and physical properties. Therefore, the objectives of this paper are to present and discuss the long-term effects of continued application of sewage sludge on the microbial biomass $\mathrm{C}$ and $\mathrm{N}$, basal respiration, metabolic quotient, enzymatic activity, total carbon and nitrogen, soils $\delta^{13} \mathrm{C}$, gas fluxes at the soilatmosphere interface, soil suppressiveness to the soilborne plant pathogens, pests and natural enemies, mites and collembolans populations, nitrate leaching, organic nitrogen mineralization rate, heavy metal contents in soil, plants and water, and soil chemical and physical characteristics under field conditions assay conducted in a tropical soil. Previous results were published by Fernandes et al. $[6,7]$, Ghini et al. [8], Dynia et al. [10], Pedrinho et al. [11], Val-Moraes [12], Alves [13], Araújo and Bettiol [14], Bettiol [15], Melo [16], Melo [17], Boeira and Maximiliano [18, 19], Silva et al. [20], Rangel et al. [21], Alcantara et al. [22], Borba et al. [23], Munhoz and Berton [24], Vieira et al. [25], Boeira and Souza [26], Filizola et al. [27], and Macedo et al. [28-30]. 
The most relevant results of this interdisciplinary approach are summarized and discussed here.

\section{Experimental Conditions}

The experiment was conducted at the Embrapa Environment Experimental Field, located in Jaguariúna, São Paulo State, Brazil (latitude $22^{\circ} 41^{\prime} \mathrm{S}$, longitude $47^{\circ} \mathrm{W}$ ). The altitude of the site is $570 \mathrm{~m}$ a.s.l. The climate type is humid subtropical; mean annual rainfall is $1335.4 \mathrm{~mm}$, and mean annual temperature is $21.7^{\circ} \mathrm{C}$ [31]. The soil at the experimental area was a dark red distroferric latosol (clayey texture) which physical and chemical characteristics in the $0-20 \mathrm{~cm}$ layer, before the onset of the study follows: $\mathrm{pH}$ in water $=5.8$; OM $=25.5 \mathrm{~g} \mathrm{~kg}^{-1} ; \mathrm{P}=3.5 \mathrm{mg} \mathrm{cm}^{-3} ; \mathrm{K}=1.51, \mathrm{Ca}=27.5, \mathrm{Mg}=8.5$, $\mathrm{Al}=1, \mathrm{H}=35$, and $\mathrm{CEC}=73.5 \mathrm{mmol} \mathrm{dm}{ }^{-3} ; \mathrm{BS} \%=50.8$; and clay $=450 \mathrm{~g} \mathrm{~kg}^{-1}[6,7,21]$.

The different sewage sludge were obtained from biological or secondary wastewater treatment plants located in Barueri, São Paulo, which treats domestic and industrial sewage (Barueri Sludge), and in Franca, São Paulo, which treats only domestic sewage (Franca sludge). Both plants employ activated sludge process. The most important characteristics of these two types of sludge were earlier described in Bettiol et al. [32] and are presented in Table 1.

The study treatments were: control (C), mineral fertilization (NPK) recommended for the crop [33], sewage sludge applied based on the $\mathrm{N}$ concentration that provides the same amount of $\mathrm{N}$ as in the mineral fertilization recommended for the corn $-90 \mathrm{kgha}^{-1}$ [33] (1N), and two $(2 \mathrm{~N})$, four $(4 \mathrm{~N})$, and eight $(8 \mathrm{~N})$ times the $\mathrm{N}$ recommended dosage for the corn crop. Calculations of sludge rates were performed as a function of the $\mathrm{N}$ available for plants, considering the $\mathrm{N}$ mineralization rate as $30 \%$. Supplementary K was applied for treatments involving sewage sludge, when necessary [34]. The wet sludge had been incorporated annually in six applications, since 1999 (April and December 1999, October 2000, November 2001, November 2002, and December 2003). It was toss distributed in the total area of the experimental plots and incorporated to a depth of $20 \mathrm{~cm}$ with a rotary harrow, 3-4 days before sowing.

In the first year, the corn variety cultivated was CATI AL30, and sowing was done on April/05/1999 (minicrop); in the second year, the hybrid AG1043 was cultivated and sowing was on December/13/1999; in the third, fourth, fifth, and sixth years, the hybrid Savanna $133 \mathrm{~S}$ was used, sown on October/30/2000, November/05/2001, November/22/2002, and December/18/2003. For the third cultivation, the $\mathrm{pH}$ was corrected individually in each plot to $\mathrm{pH} 5.7$, one month before sludge application, based on a soil-neutralizing curve. The agricultural practices adopted were those traditionally utilized locally for the crop without irrigation. The stubble was removed from the plots before sludge application. Table 2 displays the amounts of sludge and fertilizers applied in each treatment during the six corn cropping seasons.

The experimental design was set up as completely randomized split blocks with three replications. Each plot measured $10 \mathrm{~m} \times 20 \mathrm{~m}$, with 12 rows per plot. The plots were separated by hedgerows with at least $5 \mathrm{~m}$ on each side, planted with Bracchiaria sp. grass kept at a short height.

\section{Effect of Sewage Sludge on Soil Microbial Activity}

The application of sewage sludge can either stimulate soil microbial activity, due to an increase in available carbon and nutrients, or inhibit activity, due to the presence of heavy metals and other pollutants $[35,36]$. Soil respiration, metabolic quotient, and soil enzymatic activity have been adequate indicators for microbial activity and of modifications occurred in the soil to evaluate the effects of sewage sludge disposal in agriculture and forestry soils [7, 37-40].

The effect of long-term and continued application of sewage sludge rates on microbial biomass, basal respiration, metabolic quotient, and enzymatic activity was studied by Fernandes et al. [6] after four application of Barueri sewage sludge under field conditions in Jaguariúna assay (Tables 1 and 2). These authors observed that soil microbial biomass values for $\mathrm{C}$ and $\mathrm{N}$ varied significantly with different sewage sludge doses and sampling seasons, and their values were positively correlated with sewage sludge doses; the basal respiration, $\mathrm{qCO}_{2}$ and soil enzymatic activity increased as the sewage sludge doses added to the soil increased; there was a significant correlation between $\mathrm{C}$ and $\mathrm{N}$ in the microbial biomass and $\mathrm{C}$ and $\mathrm{N}$ from amylase and urease activities, and repeated applications of sewage sludge would eventually lead to a new steady state with a new balance between materials inputs and outputs. In this way, considering that agricultural use is the best sewage sludge disposal means and having been observed an increase in microbial activity proportional to sludge application, Fernandes et al. [6] recommended that the amount of sludge must be calculated based on the $\mathrm{N}$ crop needs, and application should not exceed soil capacity, returning to the same area not more frequently than every second year.

Using the method based on analysis of polymerase chain reaction (PCR) amplicons containing genes encoding $16 \mathrm{~S}$ rRNA from total soil DNA, Pedrinho [11] studied the bacterial community in soil after three applications of Barueri sewage sludge. Pedrinho [11] observed that the members of the phylum Proteobacteria were markedly predominant in the soil treated with sewage sludge, and Acidobacteria was significantly present in the control. The phyla Verrucomicrobia, Actinobacteria, and Firmicutes were found in similar frequencies in treated and untreated (control) soils. Phylogenetic analysis revealed smaller bacterial diversity for soil treated with Barueri sewage sludge, suggesting that the addition of this sewage sludge can affect the phylum richness of the soil.

The effect of Barueri sewage sludge on the structure of the bacterial communities through DNA microarray analysis was studied by Val-Moraes [12] after five applications. Despite the fact that $1 \mathrm{~N}$ dose of sewage sludge did not reduce the bacterial community of soil, there was a change in community structure. The dose of $8 \mathrm{~N}$ drastically reduced the majority of the representatives of the phyla, including Chloroflexi, Planctomycetes, and Verrucomicrobia which has 
TABLE 1: Chemical characteristics of sewage sludge utilized in experiments.

\begin{tabular}{|c|c|c|c|c|c|c|c|c|c|c|c|c|c|}
\hline \multirow{2}{*}{ Characteristcs } & \multirow{2}{*}{ Unit $^{(\mathrm{a})}$} & \multicolumn{2}{|c|}{ First cultivation } & \multicolumn{2}{|c|}{ Second cultivation } & \multicolumn{2}{|c|}{ Third cultivation } & \multicolumn{2}{|c|}{ Fourth cultivation } & \multicolumn{2}{|c|}{ Fifth cultivation } & \multicolumn{2}{|c|}{ Sixth cultivation } \\
\hline & & BS & FS & BS & FS & BS & FS & BS & FS & BS & FS & BS & FS \\
\hline $\mathrm{Ar}$ & $\mathrm{mg} \mathrm{kg}^{-1}$ & $<1$ & $<1$ & $<1$ & $<1$ & $<1$ & $<1$ & $<0.01$ & $<0.01$ & $<0.1$ & $<0.1$ & $<0.01$ & $<0.01$ \\
\hline $\mathrm{Al}$ & $\mathrm{mg} \mathrm{kg}^{-1}$ & 28,781 & 32,564 & 25,300 & 33,500 & 23,283 & 23,317 & 11,959 & 18,189 & 14230.7 & 21672.2 & 15063 & 30302 \\
\hline $\mathrm{Cd}$ & $\mathrm{mg} \mathrm{kg}^{-1}$ & 12.8 & 3.32 & 9.5 & 2.0 & 9.4 & 2.05 & 16.2 & 1.14 & 14.0 & 0.6 & 14.1 & 1 \\
\hline $\mathrm{Pb}$ & $\mathrm{mg} \mathrm{kg}^{-1}$ & 364.4 & 199.6 & 233 & 118 & 348.9 & 140.5 & 137.9 & 78.6 & 148.7 & 43.0 & 127 & 26.6 \\
\hline $\mathrm{Cu}$ & $\mathrm{mg} \mathrm{kg}^{-1}$ & 1058 & 239.8 & 1046 & 359 & 953.0 & 240.9 & 682.8 & 187.1 & 867.8 & 196.0 & 805 & 152 \\
\hline Cr total & $\mathrm{mg} \mathrm{kg}^{-1}$ & 823.8 & 633.8 & 1071 & 1325 & 1297.2 & 1230.3 & 609.3 & 202.0 & 639.6 & 182.4 & 700 & 128 \\
\hline $\mathrm{Fe}$ & $\mathrm{mg} \mathrm{kg}^{-1}$ & 54,181 & 33,793 & 32,500 & 31,700 & 37,990 & 24,176 & 39,058 & 39,895 & 32,100 & 64,900 & 31,892 & 77,997 \\
\hline $\mathrm{Hg}$ & $\mathrm{mg} \mathrm{kg}^{-1}$ & $<0.01$ & $<0.01$ & $<1$ & $<1$ & $<0.01$ & $<0.01$ & $<0.01$ & $<0.01$ & $<0.1$ & $<0.1$ & $<0.01$ & $<0.01$ \\
\hline Mo & $\mathrm{mg} \mathrm{kg}^{-1}$ & $<0.01$ & $<0.01$ & $<1$ & $<1$ & $<0.01$ & $<0.01$ & $<0.01$ & $<0.01$ & $<0.1$ & $<0.1$ & $<0.01$ & $<0.01$ \\
\hline $\mathrm{Ni}$ & $\mathrm{mg} \mathrm{kg}^{-1}$ & 518.4 & 54.7 & 483 & 74 & 605.8 & 72.4 & 331.3 & 63.9 & 270.0 & 49.5 & 253 & 50.7 \\
\hline Se & $\mathrm{mg} \mathrm{kg}^{-1}$ & $<0.01$ & $<0.01$ & $<1$ & $<1$ & $<0.01$ & $<1$ & $<0.01$ & $<0.01$ & $<0.1$ & $<0.1$ & $<0.01$ & $<0.01$ \\
\hline $\mathrm{Zn}$ & $\mathrm{mg} \mathrm{kg}^{-1}$ & 2821 & 1230 & 3335 & 1590 & 3372 & 1198 & 2327.9 & 773.0 & 3330.0 & 890.6 & 2888 & 640 \\
\hline B & $\mathrm{mg} \mathrm{kg}^{-1}$ & 36.2 & 40.7 & 11.2 & 7.1 & 29.3 & 19.7 & 10.7 & 10.4 & 17.6 & 13.6 & 11.1 & 3.2 \\
\hline C organic & $\mathrm{g} \mathrm{kg}^{-1}$ & 248.2 & 305.1 & 271 & 374 & 292.9 & 382.4 & 354.2 & 370.9 & 534.4 & 475.4 & 312 & 200 \\
\hline $\mathrm{pH}$ & & 6.6 & 6.3 & 6.4 & 6.4 & 6.4 & 5.4 & 8.5 & 8.9 & 8.0 & 8.3 & 8.3 & 7.8 \\
\hline Humidity $^{\text {(b) }}$ & $\%$ & 66.4 & 83 & 80.2 & 82.4 & 71.2 & 82.7 & 79.5 & 74.6 & 78.8 & 78.5 & 81.2 & 75 \\
\hline Volatile solids & $\%$ & 43.0 & 60.5 & - & - & 56.8 & 72.5 & 62.6 & 67.0 & 59.6 & 58.65 & 62 & 42 \\
\hline N Total ${ }^{(b)}$ & $\mathrm{g} \mathrm{kg}^{-1}$ & 21 & 56.4 & 49.7 & 67.5 & 42.1 & 68.2 & 50.8 & 49.7 & 79.7 & 57.7 & 43.5 & 32.2 \\
\hline $\mathrm{F}$ & $\mathrm{g} \mathrm{kg}^{-1}$ & 15.9 & 16.0 & 31.2 & 21.3 & 26.9 & 12.9 & 17.7 & 13.8 & 17.9 & 27.3 & 16.1 & 18.3 \\
\hline $\mathrm{P}$ & $\mathrm{g} \mathrm{kg}^{-1}$ & 1.0 & 1.0 & 1.97 & 0.99 & 1.0 & 1.0 & 1.5 & 1.5 & 1.0 & 1.0 & 1.2 & 0.7 \\
\hline $\mathrm{Na}$ & $\mathrm{g} \mathrm{kg}^{-1}$ & 0.5 & 0.5 & 0.6 & 0.6 & 0.5 & 0.9 & 0.5 & 0.5 & 0.9 & 0.4 & 0.3 & 0.3 \\
\hline S & $\mathrm{g} \mathrm{kg}^{-1}$ & 13.4 & 16.3 & 10.8 & 13.3 & 17.1 & 15.7 & 11.7 & 9.3 & 14.5 & 10.1 & 12.6 & 6.5 \\
\hline $\mathrm{Ca}$ & $\mathrm{g} \mathrm{kg}^{-1}$ & 40.3 & 29.2 & 22.8 & 16.8 & 47.8 & 24.8 & 20.1 & 13.3 & 19.4 & 11.5 & 13.4 & 10.4 \\
\hline $\mathrm{Mg}$ & $\mathrm{g} \mathrm{kg}^{-1}$ & 3.0 & 2.2 & 3.7 & 2.5 & 4.5 & 2.2 & 3.7 & 2.7 & 3.8 & 5.0 & 2.8 & 1.5 \\
\hline $\mathrm{Mn}$ & $\mathrm{mg} \mathrm{kg}^{-1}$ & 429.5 & 349.3 & 335 & 267 & 418.9 & 232.5 & 277.5 & 439.8 & 246.9 & 712.9 & 209 & 683 \\
\hline
\end{tabular}

Concentration values given are based on dry matter. ${ }^{(a)}$ Determined according EPA SW-846-3051 (1986), in IAC (Campinas, São Paulo). ${ }^{(b)}$ Concentration values for $\mathrm{N}$ total and humidity were determined in the sample under the original conditions, in Embrapa Environment. EPA, 1986. Test methods for evaluating solid waste, physical/chemical methods. US Environmental Protection Agency. Office of solid waste and emergency response, third ed. U.S. Government Office, Washington, DC, SW-846-3051.

representatives directly associated with sewage sludge. On the other hand, other favored phyla include Bacteroidetes, candidate divisions OD1, OP11, and OS-K, and Spirochaetes. The candidates divisions OD1 and OP11 are related to the sulfur cycle, and this soil had a high $S$ rate. However, the Spirochaetes are generally pathogenic. The candidate division OS-K has not yet determined the ecological role in the environment, but it is probably related to the cycle of sulfur and phosphorus. The author concluded that bacterial communities were most affected by the dose $8 \mathrm{~N}$, indicating that high doses of Barueri sewage sludge completely alter the bacterial communities.

\section{Sewage Sludge Effects on Gas Fluxes at the Soil-Atmosphere Interface, on Soil $\delta^{13} \mathrm{C}$, and on Total Soil Carbon and Nitrogen}

Application of sewage sludge under temperate soil climates increases the emission of $\mathrm{CO}_{2}, \mathrm{~N}_{2} \mathrm{O}$ and $\mathrm{CH}_{4}$ [41-43], but in tropical soils that received sludge applications, there are few studies. To study gases emissions from tropical treated soils, Fernandes et al. [7] collected the samples of gases $\left(\mathrm{CO}_{2}, \mathrm{~N}_{2} \mathrm{O}\right.$, and $\left.\mathrm{CH}_{4}\right)$ in the soil treated with Barueri sewage sludge (i) before the sludge application corresponding to the third corn cultivation, (ii) at the end of the third cultivation, (iii) before the sludge application corresponding to the fourth cultivation, (iv) 33 days after sludge application prior to the corn planting corresponding to the fourth cultivation, and (v) at the end of the fourth cultivation (Tables 1 and 2). The measurements of gas emission rates were made according to Bowden et al. [44] and Fernandes et al. [45]. In this study, Fernandes et al. [7] observed that the application of sewage sludge caused an increased flux of $\mathrm{CO}_{2}, \mathrm{~N}_{2} \mathrm{O}$, and $\mathrm{CH}_{4}$ to the atmosphere by $224 \%, 316 \%$, and $162 \%$, respectively, for the highest sewage sludge rate, when compared to the control. There was an increase in the flux of $\mathrm{CO}_{2}, \mathrm{~N}_{2} \mathrm{O}$, and $\mathrm{CH}_{4}$ to the atmosphere of $85 \%, 45 \%$, and $106 \%$ for the NPK treatment, when compared to the control. However, when the highest sludge rate was compared to the 
TABLE 2: Franca sewage sludge (FS), Barueri sewage sludge (BS), and mineral fertilizer (NPK) amounts applied in six corn cultivations.

\begin{tabular}{|c|c|c|c|c|c|c|c|c|c|c|c|c|c|c|c|c|c|c|}
\hline \multirow{3}{*}{ Treatment } & \multicolumn{6}{|c|}{ Sewage sludge $\left(\mathrm{kg} \mathrm{ha}^{-1}\right.$ dry matter $)$} & \multirow{2}{*}{\multicolumn{6}{|c|}{$\begin{array}{c}\mathrm{N}(\text { cultivation }+ \text { coverage })+\mathrm{P}_{2} \mathrm{O}_{5}\left(\mathrm{~kg} \mathrm{ha}^{-}\right) \\
\text {Cropping }\end{array}$}} & \multirow{2}{*}{\multicolumn{6}{|c|}{$\begin{array}{c}\mathrm{K}_{2} \mathrm{O}\left(\mathrm{kg} \mathrm{ha}^{-}\right) \\
\text {Cropping }\end{array}$}} \\
\hline & & & Crop & oping & & & & & & & & & & & & & & \\
\hline & $1^{\circ}$ & $2^{\circ}$ & $3^{\circ}$ & $4^{\circ}$ & $5^{\circ}$ & $6^{\circ}$ & $1^{\circ}$ & $2^{\circ}$ & $3^{\circ}$ & $4^{\circ}$ & $5^{\circ}$ & $6^{\circ}$ & $1^{\circ}$ & $2^{\circ}$ & $3^{\circ}$ & $4^{\circ}$ & $5^{\circ}$ & $6^{\circ}$ \\
\hline C & - & - & - & - & - & - & - & - & - & - & - & - & - & - & - & - & - & - \\
\hline \multirow[t]{2}{*}{ NPK } & - & - & - & - & - & - & $16+34$ & $18+72$ & $18+82$ & $20+70$ & $20+80$ & $20+50$ & 64 & 72 & 72 & 56 & 70 & 50 \\
\hline & & & & & & & 80 & 90 & 90 & 70 & 70 & 70 & & & & & & \\
\hline $\mathrm{F} 1 \mathrm{~N}$ & 3014 & 3504 & 3766 & 4432 & 4300 & 5720 & - & - & - & - & - & - & 28 & 33 & 58 & 96 & 63 & 39.1 \\
\hline $\mathrm{F} 2 \mathrm{~N}$ & 6028 & 7008 & 7533 & 8863 & 8700 & 11450 & - & - & - & - & - & - & 25 & 29 & 45 & 90 & 54 & 29.1 \\
\hline F4N & 12057 & 14017 & 15065 & 17726 & 17400 & 22890 & - & - & - & - & - & - & 17 & 23 & 18 & 75 & 36 & 6.1 \\
\hline $\mathrm{F} 8 \mathrm{~N}$ & 24113 & 26033 & 30131 & 35452 & 34800 & 45790 & - & - & - & - & - & - & - & 11 & - & 42 & 3 & - \\
\hline $\mathrm{C}$ & - & - & - & - & - & - & - & - & - & - & - & - & - & - & - & - & - & - \\
\hline \multirow[t]{2}{*}{ NPK } & - & - & - & - & - & - & $16+34$ & $18+72$ & $18+82$ & $20+70$ & $20+80$ & $20+50$ & 64 & 72 & 72 & 56 & 72 & 50 \\
\hline & & & & & & & 80 & 90 & 90 & 70 & 70 & 70 & & & & & & \\
\hline $\mathrm{B} 1 \mathrm{~N}$ & 8095 & 3995 & 5315 & 5295 & 3200 & 3880 & - & - & - & - & - & - & 3 & 28 & 40 & 87 & 57 & 35.6 \\
\hline $\mathrm{B} 2 \mathrm{~N}$ & 16190 & 7991 & 10631 & 10591 & 6500 & 7770 & - & - & - & - & - & - & - & 19 & 8 & 69 & 45 & 21.2 \\
\hline $\mathrm{B} 4 \mathrm{~N}$ & 32381 & 15981 & 21262 & 21182 & 12900 & 15530 & - & - & - & - & - & - & - & 4 & - & 33 & 21 & - \\
\hline $\mathrm{B} 8 \mathrm{~N}$ & 64762 & 31962 & 42524 & 42363 & 25800 & 31060 & - & - & - & - & - & - & - & - & - & - & - & - \\
\hline
\end{tabular}

FS: sewage sludge from the Franca Wastewater Treatment Plant. BS: sewage sludge from Barueri Wastewater Treatment Plant. C: control; NPK: mineral fertilization recommended for the crop; F1N, F2N, F4N, and F8N: SS from Franca based on the nitrogen concentration that provides the same amount of $\mathrm{N}$ as in the mineral fertilization, one, two, four, and eight times the $\mathrm{N}$ recommended sewage sludge dosage, respectively; B1N, B2N, B4N, and B8N: sewage sludge from Barueri based on the nitrogen concentration that provides the same amount of $\mathrm{N}$ as in the mineral fertilization, one, two, four, and eight times the $\mathrm{N}$ recommended sewage sludge, respectively.

NPK treatment, the increases in the fluxes of $\mathrm{CO}_{2}, \mathrm{~N}_{2} \mathrm{O}$, and $\mathrm{CH}_{4}$ to the atmosphere were $75 \%, 186 \%$, and $27 \%$. These results demonstrate that NPK and sewage sludge changed the rate of mineralization of soil organic matter; consequently, there were greater fluxes of $\mathrm{CO}_{2}, \mathrm{~N}_{2} \mathrm{O}$, and $\mathrm{CH}_{4}$ to the atmosphere as compared with the control.

In soils treated with Barueri sewage sludge, Fernandes et al. [7] also studied soil $\delta^{13} \mathrm{C}$ and on total soil carbon and nitrogen. The soil $\mathrm{C}$ contents at the highest sewage sludge rate increased by $55 \%$ and $48 \%$ at the layers from 0 to $10 \mathrm{~cm}$ and from 10 to $20 \mathrm{~cm}$, respectively, as compared to the control. In the case of soil $\mathrm{N}$, the increase was in the order of $59 \%$ and $66 \%$ at the highest sludge rate at the layers from 0 to $10 \mathrm{~cm}$ and from 10 to $20 \mathrm{~cm}$, respectively, relative to the control. The increase in soil $\mathrm{C}$ content was derived from the sewage sludge, as demonstrated by $\delta^{13} \mathrm{C}$ analyses, and, since the soil's $\delta^{13} \mathrm{C}$ contents were negative, it was suggested that the soil was sequestering carbon contained in the sewage sludge. Similar results were obtained by Alves [13] for Franca sewage sludge after five applications for soil $\mathrm{C}$ and $\mathrm{N}$ contents and $\delta^{13} \mathrm{C}$ analyses.

After six applications of Barueri sewage sludge, De Oliveira Dias et al. [46] observed that the sewage sludge applications increased the $\mathrm{C}$ content and stock rose in the 0 to $20 \mathrm{~cm}$ soil layer. Most soil C $(50 \%-66 \%)$ was associated to the humic pool, followed by fulvic acid fraction- $\mathrm{C}$ and then humic acid fraction-C. Sewage sludge applications resulted in higher contents of C-humic substances in soil though the proportion of mineralized $\mathrm{C}$ in soil humus remained unchanged.

\section{Effect of Sewage Sludge on Suppressiveness to Soil-Borne Plant Pathogens and Spodoptera frugiperda}

The effect of six applications at the rates of one $(1 \mathrm{~N})$, two $(2 \mathrm{~N})$, four $(4 \mathrm{~N})$, and eight $(8 \mathrm{~N})$ times the $\mathrm{N}$ recommended doses for the corn crop and types of sewage sludge (Barueri and Franca sewage sludge) [32] on soil suppressiveness to Fusarium oxysporum f. sp. lycopersici, Sclerotium rolfsii, Sclerotinia sclerotiorum, Rhizoctonia solani, Pythium spp., and Ralstonia solanacearum was evaluated by methods using indicator host plants, baits, and mycelial growth by Ghini et al. [8]. The effects of sewage sludge varied depending on the pathogen, methodology applied, and on the time interval between the sewage sludge incorporation and soil sampling. In general, both types of sewage sludge increased suppressiveness of the soil to diseases caused by $S$. rolfsii in bean, $R$. solani in radish, and $R$. solanacearum in tomato plants but decreased suppressiveness to those caused by $S$. sclerotiorum in tomato and Pythium spp. in cucumber and had no effect on disease associated with Fusarium oxysporum f. sp. lycopersici in tomato plants.

Araújo and Bettiol [14] conducted two experiments to evaluate the effects of sewage sludge on seedling emergence, damping-off incidence, and severity of $R$. solani and Macrophomina phaseolina in soybean using soil samples collected in the Jaguariúna experiment [32] after four (1999 to 2001) successive applications of sewage sludge (Tables 1 and 2). In this case, the experiments were conducted in pots and the soil was artificially infested with the pathogens. 
In such study, there were no treatment effects on the suppressiveness of $R$. solani and M. phaseolina [14]. Those authors, in the same soils, evaluated the effect of sewage sludge on the severity soybean powdery mildew (Erysiphe diffusa), and observed that the disease severity was reduced with of increase in the concentration of sludge in the soil.

The effect of sewage sludge on the incidence of corn stalk rot caused by Fusarium was studied by Bettiol [15]. The disease did not occur during the first cycle. For the $1999 / 2000$ and 2000/2001 crops, the percentage of diseased plants was positively correlated with the concentration of sewage sludge incorporated into to the soil. The coefficients of determination for the second corn cultivation were $R^{2}=$ 0.90 and $R^{2}=0.84$, while for the third cultivation, they were $R^{2}=0.77$ and $R^{2}=0.45$, for sewage sludge from Franca and Barueri, respectively. The sludge concentrations also showed positive correlation with the Fusarium population in the soil and with the electric conductivity (EC); on the other hand, they were negatively correlated with the $\mathrm{pH}$. The correlation studies between the percentage of diseased plants and the soil's chemical attributes were significant and positive, for the two sewage sludge and the two last cultivations, at the $5 \%$ level, for phosphorus content, CEC, $\mathrm{N}_{\text {total }}, \mathrm{N}-\mathrm{NO}_{3-}$, and EC; on the other hand, it was negatively correlated with the $\mathrm{pH}$. For the second cultivation, the percentage of diseased plants was positively correlated with all micronutrients ( $\mathrm{Fe}, \mathrm{B}, \mathrm{Cu}$, and $\mathrm{Zn}$ ), except for $\mathrm{Mn}$ (Figure 1). These results demonstrate that if sewage sludge is to be utilized in agriculture in a safe manner, there is a need for long-term interdisciplinary studies performed under the ecological conditions of cultivation.

Suppressiveness to soil-borne plant pathogens is one of the most important soil properties, and the applications of organic matter alter this characteristic. On the other hand, incorporation of sewage sludge into the soils can reduce or increased or did not interfere with the incidence or the severity of plant disease. In this way, the effects of sewage sludge on plant diseases should be studied further, since the production of sewage sludge continuously increasing wordwide, whose final disposal is mainly in agriculture.

After four applications of sewage sludge, Melo [16] has not verified the negative effects on Spodopera frugiperda or their natural enemies. Furthermore, they found that there was a positive effect of sewage sludge to reduce the occurrence of pests and increase natural enemies, but with unknown causes.

\section{Effect of Sewage Sludge on Mites and Collembolans Populations}

Mites and collembolans inhabitants of the soil have an important role in organic matter decomposition. The addition of organic matter in the soil usually increases the mesofauna population. However, some organic materials, like sewage sludge, containing toxic agents can cause reduction of these populations. Thus, Melo [17] studied the influence of three applications of Franca and Barueri sewage sludge on mites, and collembolans populations in the soil. The populations of collembolans were not affected by the applications. The Franca sewage sludge did not showed negative effect on the population of mites and the most favorable rates for the population of these organisms were $2 \mathrm{~N}, 4 \mathrm{~N}$, and $8 \mathrm{~N}$. Moreover, the doses of $2 \mathrm{~N}, 4 \mathrm{~N}$, and $8 \mathrm{~N}$ of Barueri sewage sludge were unfavorable to the mites in the first and second years and did not affect the population in the next application. Oribatid mites tended to adapt to the presence of Barueri sewage sludge after two applications.

\section{Nitrate Leaching after Successive Applications of Sewage Sludge}

Dynia et al. [10] evaluated nitrate leaching caused by five successive applications of sewage sludge at the rates of one $(1 \mathrm{~N})$, two $(2 \mathrm{~N})$, four $(4 \mathrm{~N})$, and eight $(8 \mathrm{~N})$ times the $\mathrm{N}$ recommended doses for the corn crop and types of sewage sludge (Barueri and Franca sewage sludge) in a soil cultivated with corn. The samples of the soil for analysis of nitrate were collected on all plots. The layers were 0 to $0.2,0.2$ to 0.6 , 0.6 to $1.0,1.0$ to $1.4,1.4$ to $1.8,1.8$ to $2.2,2.2$ to 2.6 , and 2.6 to $3.0 \mathrm{~m}$. The nitrate in the soil samples were extracted with solution of sodium sulfate $0.5 \mathrm{~mol} \mathrm{~L}^{-1}$ and determined by the colorimetric method described by Baker [47]. The same method was used to determine the levels of nitrate in the samples of soil solution. $\mathrm{N}-\mathrm{NO}_{3-}$ leaching occurred in all treatments, following the order NPK $<\mathrm{C}<1 \mathrm{~N}<2 \mathrm{~N}<4 \mathrm{~N}<8 \mathrm{~N}$ similarly for Barueri and Franca sewage sludge. Mean total losses of $\mathrm{N}^{-\mathrm{NO}_{3}}$ in treatments $1 \mathrm{~N}, 2 \mathrm{~N}, 4 \mathrm{~N}$, and $8 \mathrm{~N}$ reached $430,1,020,2,400$, and $3,970 \mathrm{~kg} \mathrm{ha}^{-1}$, respectively, $(28 \%, 42 \%, 54 \%$ and $45 \%$ of the total $\mathrm{N}$ applied, resp.). Treatments $2 \mathrm{~N}, 4 \mathrm{~N}$, and $8 \mathrm{~N}$ showed the greatest soil solution $\mathrm{N}-\mathrm{NO}_{3-}$ concentrations during the fourth cultivations, with peak values varying between $86 \mathrm{mg} \mathrm{L}^{-1}$ (treatment $2 \mathrm{~N}$ ) and $464 \mathrm{mg} \mathrm{L}^{-1}$ (treatment $8 \mathrm{~N}$ ). In treatments NPK, C, and $1 \mathrm{~N}$, soil solution $\mathrm{N}-\mathrm{NO}_{3-}$ concentrations during the fourth cultivations varied from 5 to 9,19 to 36 , and 33 to $71 \mathrm{mg} \mathrm{L}^{-1}$, respectively. The authors concluded that sewage sludge application, at doses corresponding to the supply of four and eight times the available $\mathrm{N}$ applied as mineral fertilizer recommended for the culture, results in intense leaching of the anion from the first crop. After five applications, much of nitrate leachate reaches a depth of $3 \mathrm{~m}$.

\section{Organic Nitrogen Mineralization Rate Following the Fourth Sewage Sludge Application}

According to Boeira and Maximiliano [18, 19], the available $\mathrm{N}$ in sewage sludge-amended soils is one of the restrictive factors for residue application in great amounts. This criterion must be considered in regulations for agricultural use of sewage sludge to avoid nitrate enrichment because of its potential to pollute subsurface water bodies. to determine the maximum amounts to be applied to a specific crop, some sewage sludge and soil properties should be known. One is the fraction of organic $\mathrm{N}$ of the waste that will be mineralized during the crop cycle. This quantity, combined with mineral $\mathrm{N}$ in the sludge, determines the amount of $\mathrm{N}$ 


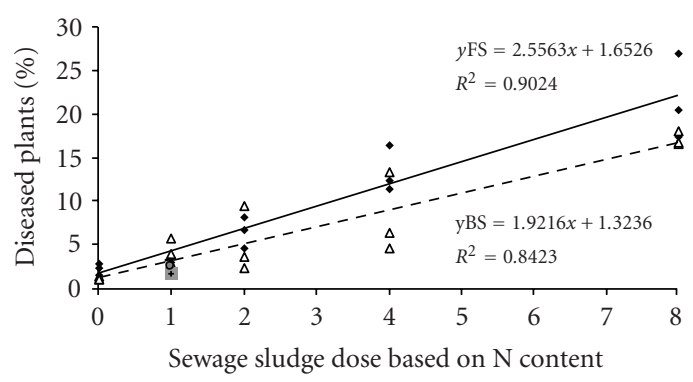

(a)

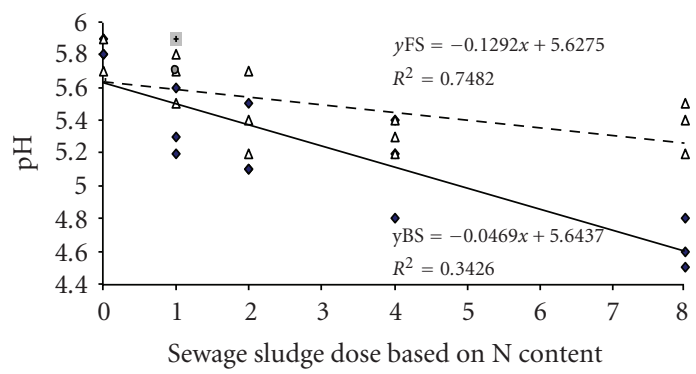

(c)

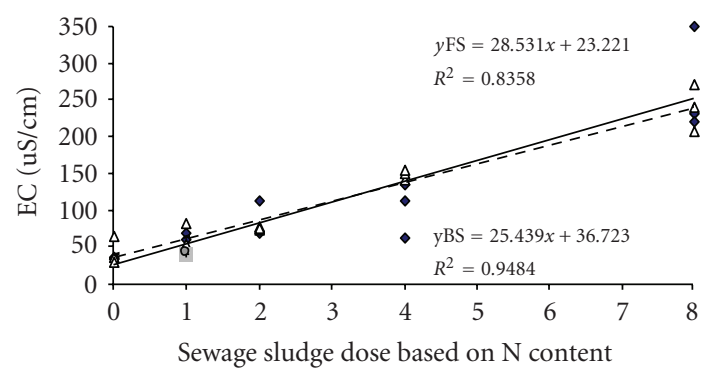

(e)

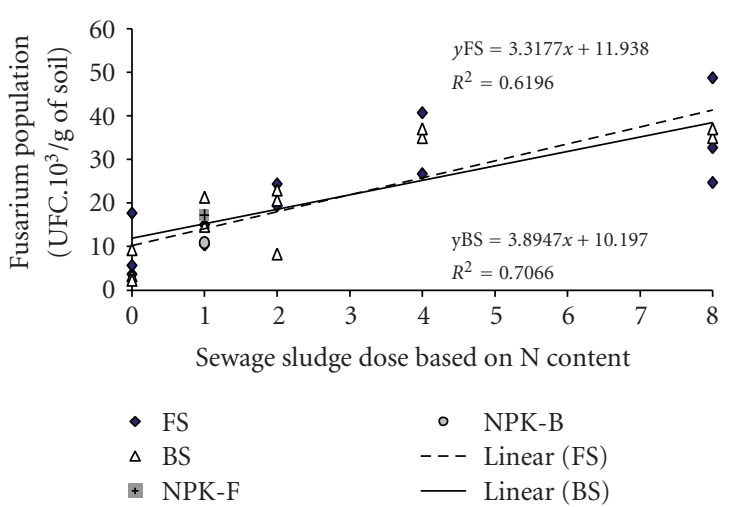

(g)

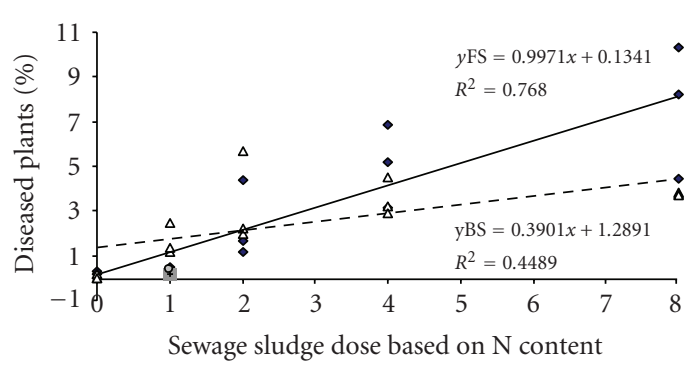

(b)

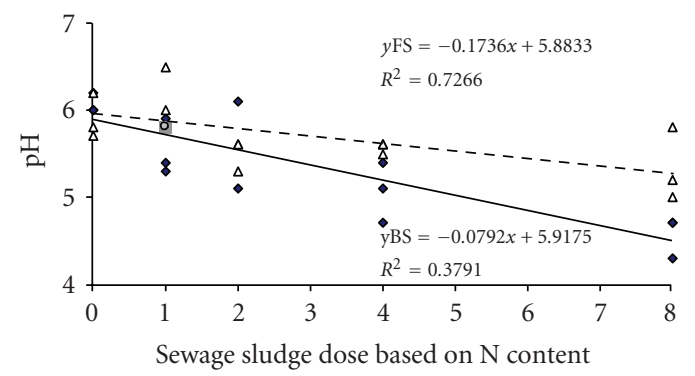

(d)

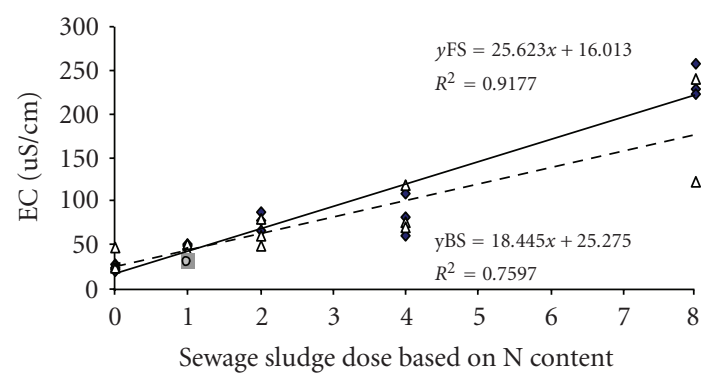

(f)

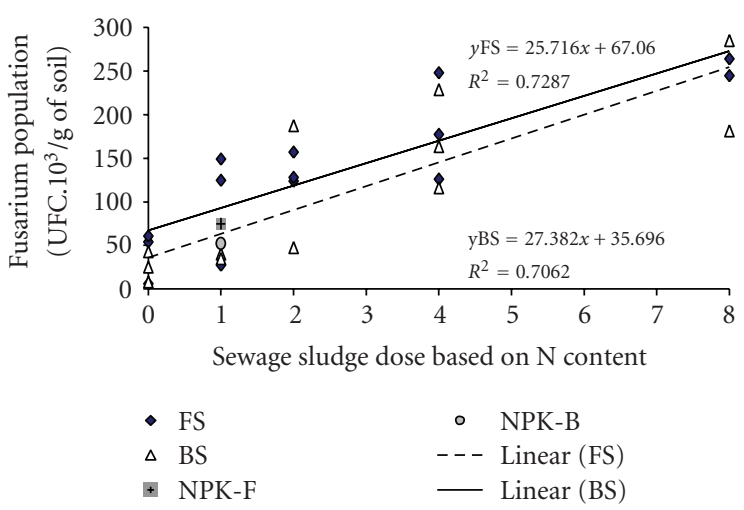

(h)

Figure 1: Effect of sewage sludge rates (FS: Franca sludge; BS: Barueri Sludge; NPK-F: recommended mineral fertilization compared to Franca sludge; NPK-B: recommended mineral fertilization compared to Barueri sludge) over the percentage of diseased plants, $\mathrm{pH}$ and electric conductivity of the soil, and Fusarium population in the soil. Left column contains data referring to second planting; right column refers to third planting. Bettiol [15].

in sewage sludge that will be available during the growing season [19]. The purpose of the Boeira and Maximiliano [18] study was to verify the potential availability of mineral $\mathrm{N}$ in a Latossol under corn previously treated with sewage sludge (Table 2). The $\mathrm{N}$ mineralization potential estimated by the single exponential model was $28 \mathrm{mg} \mathrm{kg}^{-1}$ for soil without sludge and ranged from 28 to $100 \mathrm{mg} \mathrm{kg}^{-1}$ for soil treated with Franca sludge and from 40 to $113 \mathrm{mg} \mathrm{kg}^{-1}$ for soil treated with Barueri sludge after four sewage sludge applications [18]. It was concluded that $\mathrm{N}$ residual effects must be considered prior to sewage sludge reapplication to a same soil. The $\mathrm{N}$ mineralization potential of soil and sewage 
sludge as well as nitrate accumulation in the soil profile has to be determined to calculate adequate sludge rates.

In a study to determine whether previous applications of sewage sludge affect the nitrogen mineralization fraction of the residue recently applied to a dark red dystroferric Latosol (Oxisol), Boeria and Maximiliano [19] showed that for reapplications on the same area, sewage sludge rates must be lower than the doses calculated for a single application, due to accumulations of organic and inorganic- $\mathrm{N}$ in the soil.

\section{Effects of Sewage Sludge Applications on Heavy Metal Contents in Soil, Corn Leaves and Grains, and Water}

The effects of long-term sewage sludge applications on heavy metal in tropical soil were studied by Silva et al. [20] and Rangel et al. [21] after three applications of Barueri and Franca sewage sludge and by Alcantara et al. [22] after five applications in the same area [32].

Silva et al. [20] quantified the total heavy metal in soil, corn leaves and grains, and available (DTPA and Mehlich1) contents of $\mathrm{Cu}, \mathrm{Mn}, \mathrm{Ni}, \mathrm{Pb}$, and $\mathrm{Zn}$. The increases in total metal contents were directly proportional to sewage sludge doses applied, and the metal content in sludge and Barueri sewage sludge application increased the $\mathrm{Cu}, \mathrm{Mn}$, $\mathrm{Ni}, \mathrm{Pb}$, and $\mathrm{Zn}$ contents extracted by DTPA solution. The authors observed that the total contents of heavy metals in soil are higher in plots fertilized with Barueri sewage sludge (originated of industrial and domestic waste) in relation to those quantified in areas treated with Franca sludge (domestic waste). Silva et al. [20] suggested that the DTPA and Mehlich-1 solutions are effective in predicting the availability of $\mathrm{Zn}$ to corn plants when leaves and grains are analyzed.

In leaves and grains of corn samples, the total concentration of metals $\mathrm{Cu}, \mathrm{Mn}, \mathrm{Ni}, \mathrm{Pb}$, and $\mathrm{Zn}$ were determined by Rangel et al. [21] in extracts obtained by nitric-perchloric digestion [48], with the recovery of the extract with distilled water, and the analytical measurements were performed by inductively coupled plasma optical emission spectrometry (ICP-OES). Those authors observed that the successive applications of sewage sludge caused increases in $\mathrm{Mn}$ and $\mathrm{Zn}$ contents in corn leaves and grains; in relation to the control treatment, the application of the highest dose of Barueri sewage sludge $(8 \mathrm{~N})$ promoted an increment of up to $270 \%$ and $625 \%$ of $\mathrm{Mn}$, and $35 \%$ and $115 \%$ of $\mathrm{Zn}$ concentration, respectively; corn leaves showed higher heavy metals contents than the grains, which implicates a greater possibility of metal transfer to the food chain in the case of this part of the plant be consumed. Rangel et al. [21] concluded that up to the third sewage sludge applications the heavy metal concentrations observed in corn leaves was lower than the levels considered phytotoxic, and their concentrations in corn grains was not high enough to make them unsuitable for human consumption.

Alcantara et al. [22] studied heavy metal partitioning in the sol cultivated with corn after five years disposal of a Franca and a Barueri sewage sludge. The levels of $\mathrm{Mn}, \mathrm{Fe}$,
$\mathrm{Zn}$, and $\mathrm{Cu}$ in corn grains and leaves increased significantly with the type and doses of sewage sludge application. Nevertheless, metal buildup in soil and plants was within the allowed limits. Besides the increasing levels of $\mathrm{Zn}, \mathrm{Cu}$, $\mathrm{Ni}$, and $\mathrm{Cr}$, amending soil with sewage sludge also alters the distribution of these metals by increasing the mobile Phases, which correlated significantly with the increase in metal extraction with two single extractants, Mehlich 1 and DTPA [22].

In conclusion, considering the results obtained by Silva et al. [20], Rangel et al. [21], and Alcantara et al. [22] and the levels established by Kabata-Pendias and Pendias [49], there is necessary to monitoring frequently the levels of heavy metals in areas receiving sewage sludge, as well as to control the quality of sludge for agricultural use periodically, because the plots treated with higher doses in the range of Barueri sewage sludge are critical to the total concentration of $\mathrm{Zn}$.

From December 2003 to March 2004, after six sewage sludge applications, Borba et al. [23] conducted the monitoring of metals and anions in the water of the unsaturated zone in one plot that received Barueri sewage sludge corresponding $8 \mathrm{~N}$. Monitoring occurred at depths 1, 2, 3, 4 , and $5 \mathrm{~m}$. The water was collected in five sampling by extracting soil solution. In samples of water, cations (Ca, $\mathrm{Mg}, \mathrm{K}, \mathrm{Al}, \mathrm{Fe}, \mathrm{Mn}$, and $\mathrm{Na}$ ) and anions $\left(\mathrm{Cl}, \mathrm{F}, \mathrm{NO}_{2}\right.$, $\mathrm{NO}_{3}, \mathrm{SO}_{4}$, and $\mathrm{PO}_{4}$ ) were analyzed by inductively coupled plasma atomic emission spectroscopy (ICP-AES) and highperformance liquid chromatography (HPLC), respectively. Heavy metals $(\mathrm{Cd}, \mathrm{Cu}, \mathrm{Ni}, \mathrm{Pb}$, and $\mathrm{Zn}$ ) were determined using a graphite furnace atomic absorption (GF-AA) and were also measured the physical and chemical parameters of the samples $(\mathrm{pH}$, conductivity, Eh) and total alkalinity obtained by volumetric method. The main ions found in soil solution were $\mathrm{Ca}, \mathrm{Mg}, \mathrm{NO}_{3}$, and $\mathrm{SO}_{4}$. The concentrations of $\mathrm{Ca}, \mathrm{NO}_{3}$, and $\mathrm{NO}_{2}$ reached their maximum values at the $2 \mathrm{~m}$ depth and were reduced at $5 \mathrm{~m}$. The $\mathrm{SO}_{4}$ showed high concentrations only at $1 \mathrm{~m}$ and was practically nonexistent at other depths. $\mathrm{Mg}$ increased up to $3 \mathrm{~m}$, where reached the highest values, and then declined. The total alkalinity, assumed as $\mathrm{HCO}_{3}$, decreased from 1 to $2 \mathrm{~m}$ and then grew continuously until $5 \mathrm{~m}$. Trace elements called attention, as Al that appeared permanently on $2 \mathrm{~m}$ depth (where the $\mathrm{pH}$ is 4.2 ), $\mathrm{Mn}$ in $3 \mathrm{~m}$ and $\mathrm{Pb}$ over all the depths. The other elements ( $\mathrm{Fe}, \mathrm{Cd}, \mathrm{Cu}, \mathrm{Ni}, \mathrm{Zn}$ ) were not detected. Among the cations, different reactions were observed: $\mathrm{Ca}$ and $\mathrm{Mg}$ were almost all entirety retained until $3 \mathrm{~m}$ depth, while $\mathrm{Pb}$ showed constant concentrations throughout the depths. The nitrate, up to $3 \mathrm{~m}$, and $\mathrm{Pb}$, at all depths, showed concentrations above those permitted by law for human consumption [50] in samples of well water, which are $44.3 \mathrm{mg} \mathrm{L}^{-1}$ and $0.010 \mathrm{mg} \mathrm{L}^{-1}$, respectively.

\section{Effects of Sewage Sludge Applications on Chemical Change in Soil and Water}

After four applications of Barueri sewage sludge, Fernandes et al. [7] observed that all sludge rates $(1 \mathrm{~N}, 2 \mathrm{~N}, 4 \mathrm{~N}$, and $8 \mathrm{~N})$ increased the concentration of soil $\mathrm{C}$ and $\mathrm{N}$ as compared to the control. The soil $\mathrm{C}$ contents at the highest sewage 
sludge rate increased by $55 \%$ and $48 \%$ at the layers from 0 to $10 \mathrm{~cm}$ and from 10 to $20 \mathrm{~cm}$, respectively, as compared to the control. In the case of soil $\mathrm{N}$, the increase was in the order of $59 \%$ and $66 \%$ at the highest sludge rate at the layers from 0 to $10 \mathrm{~cm}$ and from 10 to $20 \mathrm{~cm}$, respectively, relative to the control. The $\mathrm{C}$ and $\mathrm{N}$ concentrations, on average at all samplings, for the first $10 \mathrm{~cm}$ of soil were, respectively, $1.49 \%$ and $0.107 \%$ for the control and $2.30 \%$ and $0.17 \%$ for the highest sewage sludge rate. These increases were due to the high organic matter content in the Barueri sewage sludge, but for this sewage sludge is very important consider the heavy metals concentrations, because the origin is domestic and industrial waste. Alcantara et al. [22] observed that the application of increasing sewage sludge rates raised the level of organic carbon in soil significantly at both 0-20 and 20$40 \mathrm{~cm}$ deep, which probably affected soil cation exchange capacity (CEC) directly at both depths. The effect of the $4 \mathrm{~N}$ and $8 \mathrm{~N}$ doses was significantly different compared to the $1 \mathrm{~N}$ and $2 \mathrm{~N}$ [22]. The total humic fraction (fulvic + humic + humin) in Franca's sewage sludge was higher than in Barueri's and the nonhumic fraction was significantly higher in Barueri's [22].

Alcantara et al. [22] observed that the concentrations of phosphorus, nitrogen, sulfate, and CEC, organic carbon were positively correlated with sewage sludge dose applied to the soil. The sewage sludge doses influenced the content of $\mathrm{P}$ significantly, increasing its availability in the soil at both 0-20 and 20-40 cm deep. This was already expected, since the original $\mathrm{P}$ content in the soil was $1 \mathrm{mg} \mathrm{kg}^{-1}$. For the $8 \mathrm{~N}$ dose, the value observed was $114 \mathrm{mg} \mathrm{kg}^{-1}$ after five sewage sludge applications [22]. This result indicates that the use of sewage sludge is important to increase P content in tropical soil.

Phosphorus availability to corn plants in soil receiving Barueri and Franca sewage sludge was studied by Munhoz and Berton [24] after two applications. The Franca and Barueri sewage sludge had an efficiency of $34 \%$ in supplying P to corn, while the sewage sludge from Franca showed 64\% and Barueri only $16 \%$ efficiency when compared to mineral source. The sewage sludge decreased binding energy and soil $\mathrm{P}$ adsorption capacity without changing the phosphorus maximum adsorption capacity. The labile fractions $\left(\mathrm{P}-\mathrm{CaCl}_{2}\right.$ $+\mathrm{P}-\mathrm{NaHCO}_{3}$ ) and moderately labile fractions (P-NaOH) increased by $11.2 \%$ and $20.3 \%$, respectively, in detriment of most resistant fraction (residual P). According to Munhoz and Berton [24], increase in availability of sewage sludge $\mathrm{P}$ for corn can be partly explained by the decrease in the amount of $\mathrm{P}$ adsorbed by the soil and by transferring $\mathrm{P}$ from the most resistant fractions to more labile $\mathrm{P}$ pools. Addition of sewage sludge increased $\mathrm{P}$ availability to corn, but high amounts of this material decreased a binding energy to soil adsorption sites, and increasing the risk of having $\mathrm{P}$ losses by runoff towards surface water bodies.

Treatments $2 \mathrm{~N}, 4 \mathrm{~N}$, and $8 \mathrm{~N}$ showed the greatest soil solution $\mathrm{N}-\mathrm{NO}_{3}$ - concentrations during the fourth crop, with peak values varying between $86 \mathrm{mg} \mathrm{L}^{-1}$ (treatment $2 \mathrm{~N}$ ) and $464 \mathrm{mg} \mathrm{L}^{-1}$ ( $8 \mathrm{~N}$ treatment). In treatments $\mathrm{NPK}, 0 \mathrm{~N}$, and $1 \mathrm{~N}$, soil solution $\mathrm{N}-\mathrm{NO}_{3}$ - concentrations during the fourth crop varied from 5 to 9,19 to 36 , and 33 to $71 \mathrm{mg} \mathrm{L}^{-1}$, respectively [10].
Vieira et al. [25] observed that the inorganic N concentration increased with the rate of sewage sludge applications. The high $\mathrm{NO}_{3}$ - concentrations in relation to $\mathrm{NH}_{4+}$ were associated with intense soil nitrification.

After five applications of Barueri and Franca sewage sludge, the levels of $\mathrm{P}, \mathrm{Zn}, \mathrm{Cu}$, and Fe increased (Table 3 ). A positive correlation was observed between levels of $\mathrm{P}, \mathrm{Zn}$, $\mathrm{Cu}$, and $\mathrm{Fe}$ in the soil and doses of sewage sludge applied. These elements may be a limiting factor in the continued use of sewage sludge.

\section{Effects of Sewage Sludge Applications on Physical Change in Soil}

The results obtained by Boeira and De Souza [26] showed that the bulk density decreased significantly in the upper layer in response to the increasing application rates of the two sludge types.

After three applications, the sewage sludge treatments decreased the mean diameter of soil aggregates [27]. This result indicated an apparent deleterious effect of sewage sludge on soil structure. The slim plate technique utilized by Macedo et al. [28] confirms the occurrence of soil surface sealing. The sealing process increased from control to $8 \mathrm{~N}$ dose of sewage sludge.

Sewage sludge incorporated in soil with a rotary harrow acts as glue, facilitating the emergence and increasing the soil surface sealing process and crust thickness, with consequent negative influence on seed germination. Furthermore, exposure of soil surface incorporated with sewage sludge to the rain had led to the formation of crust, with subsequent appearance of surface cracks, which can increase the soil hydraulic conductivity by preferential flow, and also reduced the seed germination $[29,30]$.

\section{Concluding Remarks}

Considering that agricultural and forestry use is the best sewage sludge disposal and the results above described, we recommend that the amount of sludge must be calculated based on the $\mathrm{N}$ crop needs and annual application must be avoided to prevent overapplications. For tropical soils, the increase in $\mathrm{P}$ availability is one of the most important consequences from the sewage sludge addition to soil, but high amounts of this waste decreases a binding energy to soil adsorption sites and increases the risk of having $\mathrm{P}$ losses by runoff towards surface water bodies. The levels of $\mathrm{N}$ and $\mathrm{Zn}$ in soil increased with the rate of sewage sludge application and should be monitored. The results presented in this paper indicate that there is need to reduce the concentration of heavy metals in sewage sludge to avoid problems of soil contamination and harmful effects on the microbial community, as well as on the food produced. Thus, in areas receiving sewage sludge, soil fertility, levels of nitrate, heavy metals, and others contaminants must be frequently monitored in order to avoid negative impacts.

In August 2006, the Brazil Environment Minister (CONAMA) [51] established the Brazilian legislation on sewage sludge application in agriculture. The dose of total 
TABLE 3: Chemical characteristics of the soil after five application of Barueri (B) and Franca (F) sewage sludge.

\begin{tabular}{|c|c|c|c|c|c|c|c|c|c|c|c|c|c|}
\hline \multirow{2}{*}{ Characteristic } & \multirow{2}{*}{ Unit } & \multicolumn{6}{|c|}{ Barueri sewage sludge } & \multicolumn{6}{|c|}{ Franca sewage sludge } \\
\hline & & $\mathrm{C}$ & NPK & $\mathrm{B} 1 \mathrm{~N}$ & $\mathrm{~B} 2 \mathrm{~N}$ & $\mathrm{~B} 4 \mathrm{~N}$ & $\mathrm{~B} 8 \mathrm{~N}$ & $\mathrm{C}$ & NPK & F1N & $\mathrm{F} 2 \mathrm{~N}$ & $\mathrm{~F} 4 \mathrm{~N}$ & $\mathrm{~F} 8 \mathrm{~N}$ \\
\hline $\mathrm{pH}$ (water) & & 5.6 & 5.8 & 5.6 & 5.9 & 5.8 & 5.2 & 5.8 & 5.5 & 5.9 & 5.5 & 5.7 & 5.3 \\
\hline $\mathrm{P}$ & $\mathrm{mg} \mathrm{dm} \mathrm{m}^{-3}$ & 5.6 & 16.5 & 45.5 & 58.2 & 132.3 & 320.6 & 6.2 & 13.4 & 55.3 & 62.0 & 56.6 & 105.4 \\
\hline K & $\mathrm{mg} \mathrm{dm}{ }^{-3}$ & 32.3 & 67.3 & 40.0 & 35.3 & 30.3 & 48.0 & 35.0 & 50.7 & 41.7 & 40.3 & 31.7 & 29.3 \\
\hline $\mathrm{Ca}$ & $\mathrm{mmol}_{\mathrm{c}} \mathrm{dm}^{-3}$ & 27 & 34 & 38 & 46 & 50 & 47 & 31 & 33 & 39 & 35 & 45 & 48 \\
\hline $\mathrm{Mg}$ & $\mathrm{mmol}_{\mathrm{c}} \mathrm{dm}^{-3}$ & 16 & 21 & 14 & 16 & 15 & 18 & 17 & 12 & 18 & 19 & 19 & 14 \\
\hline $\mathrm{H}+\mathrm{Al}$ & $\mathrm{mmol}_{\mathrm{c}} \mathrm{dm}^{-3}$ & 49 & 41 & 48 & 40 & 48 & 61 & 54 & 52 & 41 & 52 & 49 & 59 \\
\hline SB & $\mathrm{mmol}_{\mathrm{c}} \mathrm{dm}^{-3}$ & 45 & 57 & 52 & 63 & 66 & 66 & 49 & 46 & 58 & 56 & 65 & 63 \\
\hline CTC & $\mathrm{mmol}_{\mathrm{c}} \mathrm{dm}^{-3}$ & 93 & 99 & 101 & 103 & 114 & 127 & 103 & 98 & 99 & 107 & 113 & 121 \\
\hline V & $\%$ & 47.2 & 57.3 & 52.0 & 60.9 & 57.3 & 52.3 & 47.4 & 47.2 & 58.8 & 51.5 & 57.1 & 51.6 \\
\hline B & $\mathrm{mg} \mathrm{dm}^{-3}$ & 0.4 & 0.7 & 0.4 & 0.5 & 0.5 & 1.0 & 0.4 & 0.3 & 0.6 & 0.5 & 0.5 & 0.5 \\
\hline $\mathrm{Cu}$ & $\mathrm{mg} \mathrm{dm} \mathrm{m}^{-3}$ & 1.9 & 1.6 & 6.5 & 10.4 & 18.8 & 43.5 & 1.5 & 1.4 & 5.1 & 3.4 & 4.0 & 5.7 \\
\hline $\mathrm{Fe}$ & $\mathrm{mg} \mathrm{dm} \mathrm{m}^{-3}$ & 47.8 & 35.8 & 57.7 & 76.8 & 103.3 & 236.9 & 44.2 & 46.5 & 86.4 & 120.2 & 114.6 & 190.8 \\
\hline $\mathrm{Mn}$ & $\mathrm{mg} \mathrm{dm} \mathrm{m}^{-3}$ & 10.2 & 9.2 & 11.2 & 11.3 & 12.5 & 13.1 & 10.2 & 11.5 & 19.2 & 19.5 & 15.2 & 16.7 \\
\hline $\mathrm{Zn}$ & $\mathrm{Mg} \mathrm{dm}^{-3}$ & 1.7 & 1.6 & 20.5 & 39.8 & 72.3 & 109.7 & 0.7 & 1.5 & 15.2 & 11.1 & 14.5 & 49.2 \\
\hline
\end{tabular}

FS: sewage sludge from the Franca Wastewater Treatment Plant. BS: sewage sludge from Barueri Wastewater Treatment Plant. C: control; NPK: mineral fertilization recommended for the crop; F1N, F2N, F4N, and F8N: SS from Franca based on the nitrogen concentration that provides the same amount of $\mathrm{N}$ as in the mineral fertilization, one, two, four, and eight times the $\mathrm{N}$ recommended sewage sludge dosage, respectively; B1N, B2N, B4N, and B8N: sewage sludge from Barueri based on the nitrogen concentration that provides the same amount of $\mathrm{N}$ as in the mineral fertilization, one, two, four, and eight times the $\mathrm{N}$ recommended sewage sludge, respectively.

sewage sludge applied in agriculture is based on sewage sludge nitrogen content and the nitrogen requirement of the cultivated crop would be the safest and recommended way to use this residue as a soil amendment. This legislation established the maximum concentrations of heavy metal and human pathogenic microorganisms on sewage sludge for agricultural and forestry disposal.

Finally, we would like to stress the importance of this pioneer study with long-term effects of continued sewage sludge application under the tropical conditions. The Jaguariúna experiment has continued for interdisciplinary studies.

\section{References}

[1] W. Bettiol and O. A. Camargo, "Reciclagem de lodo de esgoto na agricultura," in Biodegradação, I. S. Melo, C. M. M. S. Silva, S. Scramin, and A. Spessoto, Eds., pp. 93-106, Embrapa Meio Ambiente, São Paulo, Brazil, 2001.

[2] M. T. Tsutiya, "Alternativas de disposição final de biossólidos gerados em estação de tratamento de esgotos," in Impacto Ambiental do Uso Agrícola do Lodo de Esgoto, W. Bettiol and O. A. Camargo, Eds., pp. 69-105, Embrapa Meio Ambiente, Jaguariúna, 2000.

[3] W. J. Mello and M. O. Marques, "Potencial do lodo de esgoto como fonte de nutrientes para as plantas," in Impacto Ambiental do Uso Agrícola do Lodo de Esgoto, W. Bettiol and O. A. Camargo, Eds., pp. 142-193, Embrapa Meio Ambiente, São Paulo, Brazil, 200.

[4] C. V. Andreoli, Uso e manejo do lodo de esgoto na agricultura e sua influência em características ambientais no agrossistema, Ph.D. thesis, Universidade Federal do Paraná, Curitiba, Brazil, 1999.

[5] K. E. Giller, E. Witter, and S. P. Mcgrath, "Toxicity of heavy metals to microorganisms and microbial processes in agricultural soils: a review," Soil Biology and Biochemistry, vol. 30, no. 10-11, pp. 1389-1414, 1998.

[6] S. A. P. Fernandes, W. Bettiol, and C. C. Cerri, "Effect of sewage sludge on microbial biomass, basal respiration, metabolic quotient and soil enzymatic activity," Applied Soil Ecology, vol. 30, no. 1, pp. 65-77, 2005.

[7] S. A. P. Fernandes, W. Bettiol, C. C. Cerri, and P. Camargo, "Sewage sludge effects on gas fluxes at the soil-atmosphere interface, on soil $\delta \mathrm{C}$ and on total soil carbon and nitrogen," Geoderma, vol. 125, no. 1-2, pp. 49-57, 2005.

[8] R. Ghini, F. R. A. Patrício, W. Bettiol, I. M. G. de Almeida, and A. D. H. N. Maia, "Effect of sewage sludge on suppressiveness to soil-borne plant pathogens," Soil Biology and Biochemistry, vol. 39, no. 11, pp. 2797-2805, 2007.

[9] I. dos Santos and W. Bettiol, "Effect of sewage sludge on the rot and seedling damping-off of bean plants caused by Sclerotium rolfsii," Crop Protection, vol. 22, no. 9, pp. 1093-1097, 2003.

[10] J. F. Dynia, M. D. de Souza, and R. C. Boeira, "Lixiviação de nitrato em Latossolo cultivado com milho após aplicações sucessivas de lodo de esgoto," Pesquisa Agropecuaria Brasileira, vol. 41, no. 5, pp. 855-862, 2006.

[11] E. A. N. Pedrinho, E. G. M. Lemos, R. M. Pereira et al., "Avaliação do impacto do lodo de esgoto na microbiota do solo utilizando o gene 16S rRNA," Arquivos do Instituto Biológico, vol. 76, no. 3, pp. 443-448, 2009.

[12] S. P. Val-Moraes, Impacto do lodo de esgoto na comunidade bacteriana do solo: avaliação por microarranjo de DNA, Ph.D. thesis, Universidade Estadual Paulista, Jaboticabal, Brazil, 2008.

[13] S. M. C. Alves, Comportamento do carbono e do nitrogênio em latossolo vermelho distroférrrico após adição de lodo de esgoto doméstico, Ph.D. thesis, Universidade de São Paulo, Piracicaba, Brazil, 2004.

[14] F. F. de Araújo and W. Bettiol, "Efeito de lodo de esgoto sobre patógenos habitantes do solo e severidade de oídio da soja," Summa Phytopathologica, vol. 35, no. 3, pp. 184-190, 2009. 
[15] W. Bettiol, "Effect of sewage sludge on the incidence of corn stalk rot caused by Fusarium," Summa Phytopathologica, vol. 30, pp. 16-22, 2003.

[16] L. A. S. Melo, "Efeito de lodos de esgotos na ocorrência de lagarta do cartucho do milho," in Lodo de Esgoto: Impactos Ambientais na Agricultura, W. Bettiol and O. A. Camargo, Eds., pp. 235-242, Embrapa Meio Ambiente, Jaguariúna, Brazil, 2006.

[17] L. A. S. Melo, "Influência de lodos de esgotos nas populações de ácaros e colêmbolos de solo em cultura de milho," in Lodo de Esgoto: Impactos Ambientais na Agricultura, W. Bettiol and O. A. Camargo, Eds., pp. 227-234, Embrapa Meio Ambiente, Jaguariúna, Brazil, 2006.

[18] R. C. Boeira and V. C. B. Maximiliano, "Mineralização de compostos nitrogenados após aplicações de lodos de esgoto em quatro cultivos de milho," Revista Brasileira de Ciencia do Solo, vol. 33, no. 1, pp. 207-218, 2009.

[19] R. C. Boeira and V. C. B. Maximiliano, "Mineralização de compostos nitrogenados de lodos de esgoto na quinta aplicação em Latossolo," Revista Brasileira de Ciencia do Solo, vol. 33, no. 3, pp. 711-722, 2009.

[20] C. A. Silva, O. J. P. Rangel, J. F. Dynia, W. Bettiol, and C. V. Manzatto, "Disponibilidade de metais pesados para milho cultivado em latossolo sucessivamente tratado com lodos de esgoto," Revista Brasileira de Ciencia do Solo, vol. 30, no. 2, pp. 353-364, 2006.

[21] O. J. P. Rangel, C. A. Silva, W. Bettiol, and J. F. Dynia, "Efeito de aplicações de lodos de esgoto sobre os teores de metais pesados em folhas e grãos de milho," Revista Brasileira de Ciencia do Solo, vol. 30, no. 3, pp. 583-594, 2006.

[22] S. Alcantara, D. V. Pérez, M. R.A. Almeida, G. M. Silva, J. C. Polidoro, and W. Bettiol, "Chemical changes and heavy metal partitioning in an oxisol cultivated with maize (Zea mays L.) after 5 years disposal of a domestic and an industrial sewage sludge," Water, Air, and Soil Pollution, vol. 203, pp. 3-16, 2009.

[23] R. P. Borba, O. A. Camargo, W. Bettiol, C. S. Kira, and A. Sakuma, "Disposição de lodo de esgoto em solo agrícola e potencialidade de poluição do aqüífero freático raso," in III Congresso Brasileiro Gestão Ambiental e Desenvolvimento Sustentável (ICTR '06), pp. 213-216, Residue: Brazilian Challenge, Agosto 2006.

[24] R. O. Munhoz and R. S. Berton, "Disponibilidade de fósforo para o milho em solo que recebeu lodo de esgoto," in Lodo de Esgoto: Impactos Ambientais na Agricultura, W. Bettiol and O. A. Camargo, Eds., pp. 91-124, Embrapa Meio Ambiente, Jaguariúna, Brazil, 2006.

[25] R. F. Vieira, A. H. N. Maia, and M. A. Teixeira, "Inorganic nitrogen in a tropical soil with frequent amendments of sewage sludge," Biology and Fertility of Soils, vol. 41, no. 4, pp. 273-279, 2005.

[26] R. C. Boeira and M. D. de Souza, "Estoques de carbono orgânico e de nitrogénio, $\mathrm{pH}$ e densidade de um latossolo após três aplicações de lodos de esgoto," Revista Brasileira de Ciencia do Solo, vol. 31, no. 3, pp. 581-590, 2007.

[27] H. F. Filizola, M. D. Souza, M. A. F. Gomes, and R. C. Boeira, "Aspectos físicos de um solo tratado com lodo de esgoto: estabilidade de agregados e argila dispersa em água," in Lodo de Esgoto: Impactos Ambientais na Agricultura, W. Bettiol and O. A. Camargo, Eds., pp. 137-147, Embrapa Meio Ambiente, Jaguariúna, Brazil, 2006.

[28] J. R. Macedo, H. F. Filizola, M. D. Souza, and K. Reichardt, "Micromorfologia da camada superficial de solo tratado com lodo de esgoto," in Lodo de Esgoto: Impactos Ambientais na
Agricultura, W. Bettiol and O. A. Camargo, Eds., pp. 149-164, Embrapa Meio Ambiente, Jaguariúna, Brazil, 2006.

[29] J. R. Macedo, L. F. Pires, M. D. Souza, K. Reichardt, and O. O. S. Bacchi, "Selamento superficial em latossolo vermelho distroférrico tratado com lodo de esgoto," in Lodo de Esgoto: Impactos Ambientais na Agricultura, W. Bettiol and O. A. Camargo, Eds., pp. 165-191, Embrapa Meio Ambiente, Jaguariúna, Brazil, 2006.

[30] J. R. Macedo, M. D. Souza, K. Reichardt, and O. O. S. Bacchi, "Selamento superficial em latossolo vermelho distroférrico tratado com lodo de esgoto," in Lodo de Esgoto: Impactos Ambientais na Agricultura, W. Bettiol and O. A. Camargo, Eds., pp. 193-205, Embrapa Meio Ambiente, Jaguariúna, Brazil, 2006.

[31] Cepagri, "Clima dos municípios paulistas: Jaguariúna," Campinas, SP. May 2007, http://www.cpa.unicamp.br/outras-informacoes/clima_muni_283.html.

[32] W. Bettiol, O. A. Camargo, J. A. H. Galvão, and R. Ghini, "Impacto ambiental do uso agrícola do lodo de esgoto: descrição do estudo," in Lodo de Esgoto: Impactos Ambientais na Agricultura, W. Bettiol and O. A. Camargo, Eds., pp. 17-23, Embrapa Meio Ambiente, Jaguariúna, Brazil, 2006.

[33] B. Raij, H. Cantarella, J. A. Quaggio, and A. M. C. Furlani, Recomendações de Adubação e Calagem para o Estado de São Paulo, Instituto Agronômico and Fundação IAC, Campinas, Brazil, 1996.

[34] W. Bettiol and O. A. Camargo, Lodo de Esgoto Impactos Ambientais na Agricultura, Embrapa Meio Ambiente, Jaguariúna, Brazil, 2006.

[35] E. Baath, "Effects of heavy metals in soil on microbial processes and populations (a review)," Water, Air, and Soil Pollution, vol. 47, no. 3-4, pp. 335-379, 1989.

[36] W. L. Pontes, Mineralização de um biossólido industrial no solo e efeito desse na biomassa e atividade microbiana, M.Sc. dissertation, Universidade Federal de Lavras, Lavras, Brasil, 2002.

[37] R. P. Dick, "Soil enzyme assays as indicators of soil quality," in Defining Soil Quality for a Sustainable Enviroment, J. W. L. Doran, D. C. Coleman, D. F. Bezdicek, and B. A. Stewart, Eds., pp. 107-124, Soil Science Society of America, Madison, Wis, USA, 1994.

[38] R. Albiach, R. Canet, F. Pomares, and F. Ingelmo, "Microbial biomass content and enzymatic activities after the application of organic amendments to a horticultural soil," Bioresource Technology, vol. 75, no. 1, pp. 43-48, 2000.

[39] J. L. Moreno, C. García, L. Landi, L. Falchini, G. Pietramellara, and P. Nannipieri, "The ecological dose value (ED) for assessing Cd toxicity on ATP content and dehydrogenase and urease activities of soil," Soil Biology and Biochemistry, vol. 33, no. 4-5, pp. 483-489, 2001.

[40] D. A. Wardle and A. Ghani, "A critique of the microbial metabolic quotient (qCO2) as a bioindicator of disturbance and ecosystem development," Soil Biology and Biochemistry, vol. 27, no. 12, pp. 1601-1610, 1995.

[41] R. Alvarez, M. Alconada, and R. Lavado, "Sewage sludge effects on carbon dioxide-carbon production from a desurfaced soil," Communications in Soil Science and Plant Analysis, vol. 30, no. 13-14, pp. 1861-1866, 1999.

[42] R. Blechschmidt, W. Schaaf, and R. F. Hüttl, "Soil microcosm experiments to study the effects of waste material application on nitrogen and carbon turnover of lignite mine spoils in Lusatia (Germany)," Plant and Soil, vol. 213, no. 1-2, pp. 23 30, 1999. 
[43] J. W. C. Wong, K. M. Lai, M. Fang, and K. K. Ma, "Effect of sewage sludge amendment on soil microbial activity and nutrient mineralization," Environment International, vol. 24, no. 8, pp. 935-943, 1998.

[44] R. D. Bowden, P. A. Steudler, J. M. Melillo, and J. D. Aber, "Annual nitrous oxide fluxes from temperate forest soils in the northeastern United States," Journal of Geophysical Research, vol. 95, no. 9, pp. 13997-14005, 1990.

[45] S. A. P. Fernandes, M. Bernoux, C. C. Cerri, B. J. Feigl, and M. C. Piccolo, "Seasonal variation of soil chemical properties and $\mathrm{CO}$ and $\mathrm{CH}$ fluxes in unfertilized and P-fertilized pastures in an Ultisol of the Brazilian Amazon," Geoderma, vol. 107, no. 3-4, pp. 227-241, 2002.

[46] B. de Oliveira Dias, C. A. Silva, E. M. B. Soares, and W. Bettiol, "Estoque de carbono e quantificação de substâncias húmicas em latossolo submetido a aplicação contínua de lodo de esgoto," Revista Brasileira de Ciencia do Solo, vol. 31, no. 4, pp. 701-711, 2007.

[47] A. S. Baker, "Colorimetric determination of nitrate in soil and plant extracts with brucine," Journal of Agricultural and Food Chemistry, vol. 15, no. 5, pp. 802-806, 1967.

[48] M. J. Tedesco, C. Gianello, C. A. Bissani, H. Bohen, and S. J. Volkweiss, Análise de Solo, Plantas e Outros Materiais, Universidade Federal Rio Grande do Sul, Porto Alegre, 1995.

[49] A. Kabata-Pendias and H. Pendias, Trace Elements in Soil and Plants, CRC Press, Boca Raton, Fla, USA, 2001.

[50] FUNASA, Controle e Vigilância da Qualidade da Água para Consumo Humano e seu Padrão de Potabilidade, Controle e Vigilância da Qualidade da Água para Consumo Humano e seu Padrão de Potabilidade, Brasília, Brazil, 2001, Portaria $\mathrm{N}^{\circ}$ 1.469 .

[51] Conselho Nacional do Meio Ambiente, "Define criterios e procedimentos para o uso de lodos de esgoto gerados em estações de tratamento de esgoto sanitário e seus produtos derivados," Resolução no. 375, Diário Oficial da União, Brasília, DF, no. 167, pp. 141-146, August 2006. 

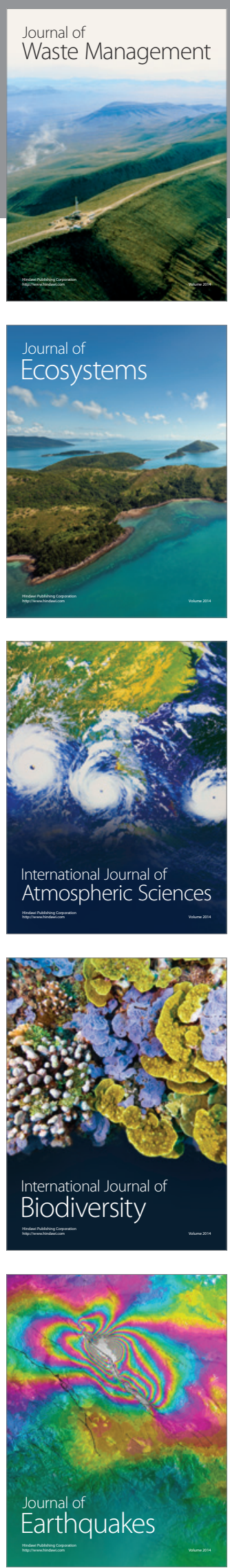
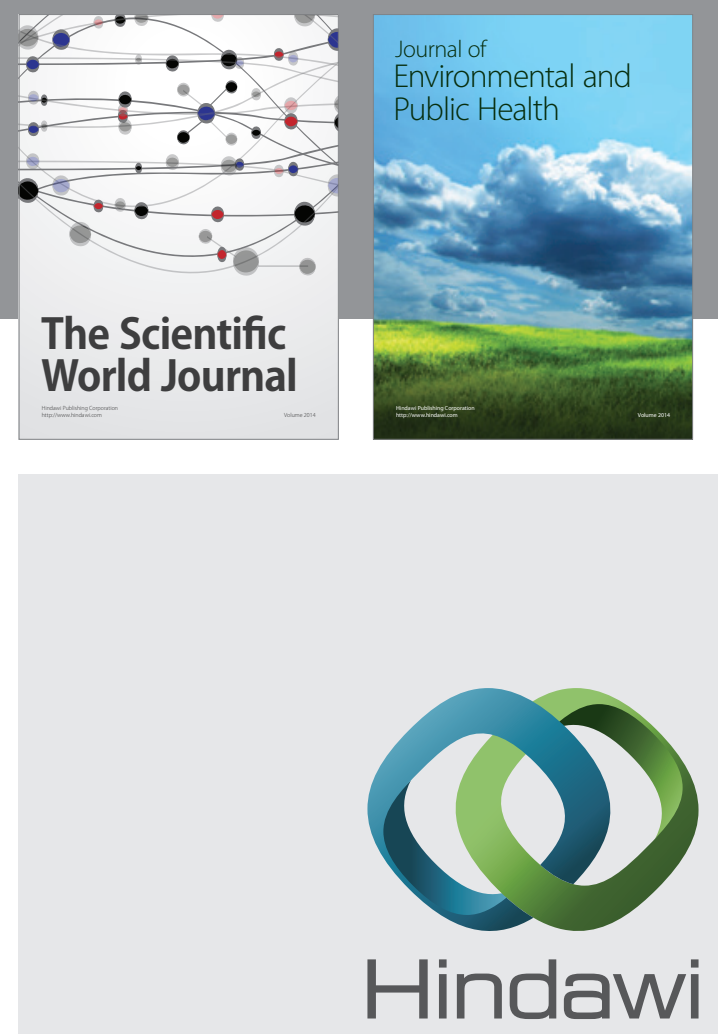

Submit your manuscripts at

http://www.hindawi.com
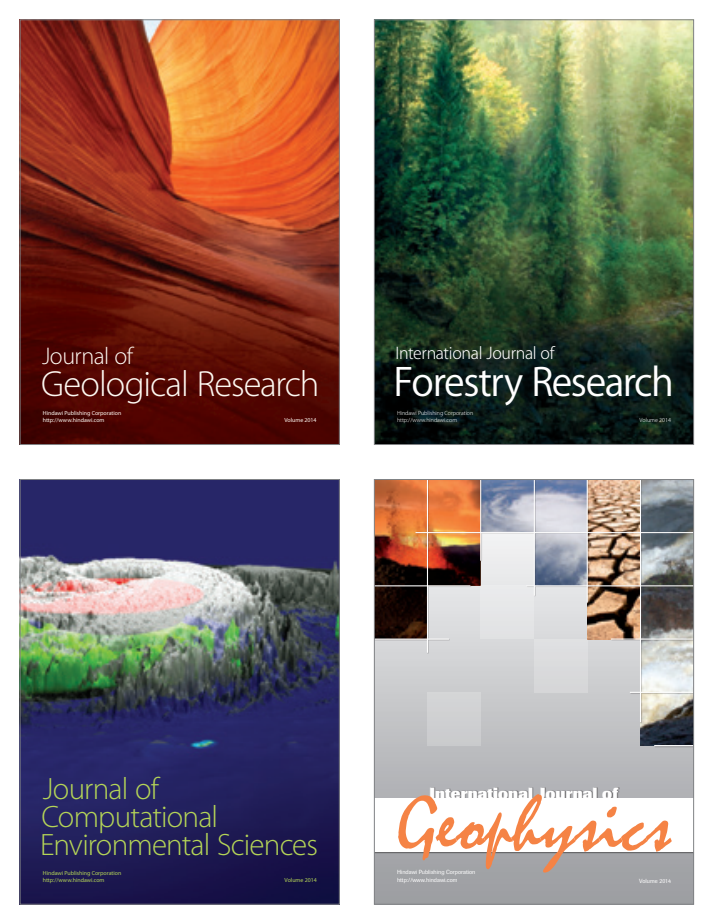
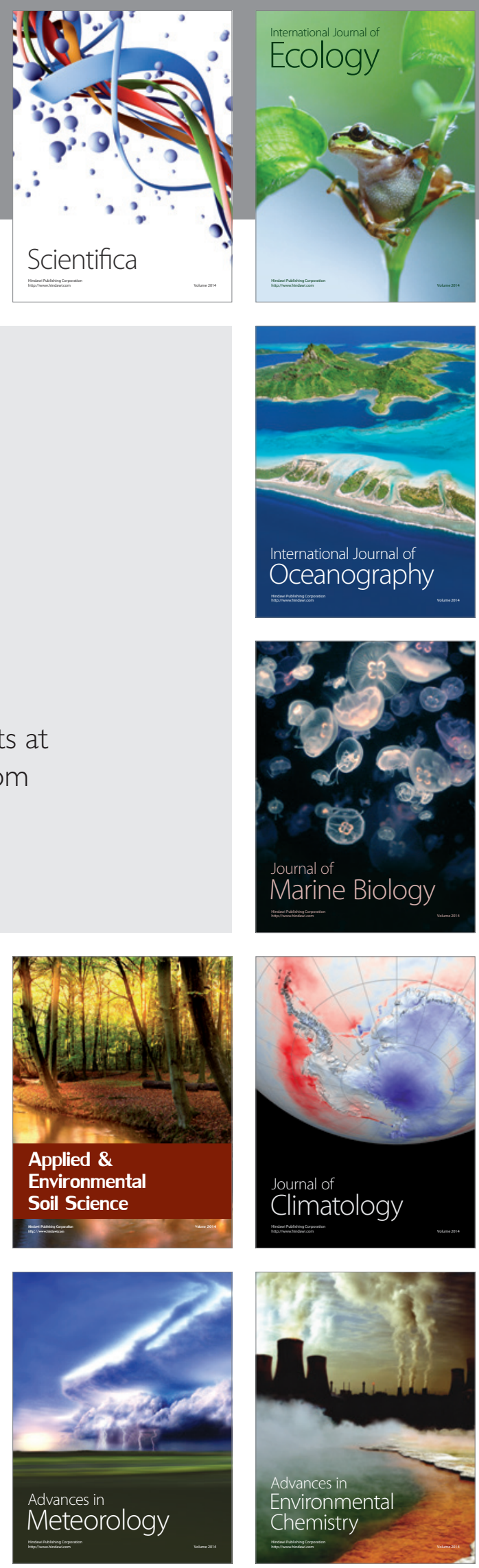